\title{
Dinamika penyelenggaraan pendidikan keagamaan Islam etnis Tionghoa muslim di Kota Padangsidimpuan
}

\author{
Asfiati Asfiati \\ Institut Agama Islam Negeri Padangsidimpuan
}

\begin{tabular}{l}
\hline Article Info \\
\hline Article history: \\
Received April 2 $2^{\text {nd }}, 2019$ \\
Revised May $20^{\text {th }}, 2019$ \\
Accepted Jun $28^{\text {th }}, 2019$
\end{tabular}

\section{Keyword:}

Muslim

Education

Religion

Tiongha

\begin{abstract}
The purpose of this research is to know the condition of Tionghoa Muslim in conducting Islamic Religion Education in Padangsidimpuan town. Tionghoa Muslim community participate in improving Islamic Religion Education in Padangsidimpuan. The reseach method is qualitative, observed instrument of collecting data, interview and documentation. The finding reseach shows that the applying Islam Religion Education grows in several center of religion instruction. The dinamycs of appliying Islam ethnic in Padangsidimpuan town is done in some places and means. The conducting Islam education in done individu and group. Concluded that Tionghoa Muslim ethnic study religion about Aqidah (believe), syariah (law), and akhlak (behavior). Lesson method build communication between instructor and learner come from several science, Islamic and Indonesian ethnic background.
\end{abstract}

Corresponding Author:

Asfiati,

Email: asfiati@asfiati.com

\section{Pendahuluan}

Padangsidimpuan merupakan salah satu kota yang berkembang dan maju. Masyarakata Padangsidimpuan terdiri dari berbagai suku: Batak, Jawa, Sunda dan ada komunitas Tionghoa muslim. Beragam suku, agama dan budaya menjadikan masyarakat Padangsidimpuan terlibat aktif dalam memajukan kota Padangsidimpuan. Salah satu upayanya adalah menyelenggarakan pendidikan keagamaan. Tionghoa muslim berpartisipasi menggerakkan pendidikan keagamaan Islam dengan cara berbaur dengan pribumi muslim lainnya (Damayanti et al., 2003).

Tionghoa muslim menyelenggarakan pendidikan keagamaan Islam berdasarkan sistem pendidikan Islam di Cina (Aroma \& Suminar, 2012). Pendidikan keagamaan umumnya dilakukan di masjid-masjid dengan sistem halaqah (A'la et al., 2019). Sistem halaqah dikenal dengan Jingtang Jiaoyu. Sistem pendidikan Islam erat kaitannya dengan sejarah Islam di nusantara. (Asfiati, 2014) The Chinese Muslim community in Indonesia has a long history, which is closely related to the history of Islam in Nusantara (Mahfud, 2018).

Islam di nusantara berkaitan erat antara Islam, Indonesia dan China. (Pratiwi et al., 2018). Dinamika pendidikan keagamaan Islam etnis Tionghoa muslim mengalami pertumbuhan dan perkembangan. (Oktafia \& Mawardi, 2017). Perkembangannya antara lain adanya pengajian majelis ta'lim. Pendidikan formal mengalami peningkatan jumlah peserta didik (Fauzi \& Nikmatullah, 2016).

Pendidikan non formal juga berkembang seperti diselenggarakannya didikan subuh dan pengajian anakanak pada malam hari.Pendidikan non formal merupakan jenis pendidikan yang diselenggarakan di lingkungan keluarga (Asfiati, 2016). Penyelenggaraan pendidikan nonformal merupakan tanggung jawab orang tua terhadap pendidikan anak. Orangtua merupakan pendidik pertama dan utama (Suryadi et al., 2018). Para orang tua etnis Tionghoa muslim terlibat dalam menyelenggarakan pendidikan keagamaan. 


\section{Urgensi kajian}

Warga etnis Tionghoa muslim mempunyai tugas dan tanggung jawab dalam memajukan pendidikan. Pada masa Kaisar Dinasti Ming, kaisar memerintahkan ulama-ulama, untuk mempelajari ilmu pengetahuan dari berbahasa Arab ke bahasa Cina (Ibrahim, 2016).

Kolaborasi bahasa China dengan bahasa Arab guna memudahkan menyelenggarakan pendidikan keagamaan. Penyelenggaraan pendidikan keagamaan dilakukan di lingkungan masyarakat etnis Tionghoa muslim, Usaha menyelenggarakan pendidikan keagamaan untuk mengajak masyarakat mempercayai kebenaran dalam Islam sebagai tugas suci yang mulia (Wekke \& Rusdan, 2017).

Oleh karena itu,semangat menyelenggarakan pendidikan keagamaan Islam etnis Tionghoa muslim untuk menyampaikan ajaran-ajaran Islam dapat dilakukan melalui pendidikan sebagai sarana transformasi ilmu pengetahuan. Pusat penyelenggaraan pendidikan dilakukan di lembaga pendiidkan sekolah dasar (SD) dn sekolah menngah pertama (SMP) di perguruan Sariputra Padangsidimpuan. Materi pelajaran tentang kajian ibadah, penanaman karakter. Penyelenggaraan pendidikan keagamaan dipandang penting. Peran etnis Tionghoa muslim dilakukan dengan cara beradaptasi dengan masyarakat mulim lainnya. Etnis Tionghoa muslim berpegang pada sumber ajaran Islam al Qur'an dan As Sunnah. Penyelenggaraan pendidikan keagamaan dari kajian kegiatan senantiasa memperhatikan materi, metode dan profesionalitas pendidik serta kemauan peserta didik. Penyelenggaraan pendidikan keagamaan sebagai bentuk semangat memperjuangkan kebenaran untuk menyampaikan ajaran-ajaran Islam kepada penduduk.

\section{Etnis tionghoa muslim di Padangsidimpuan}

Indonesia terdiri dari adat budaya yang berbeda sebagai ciri khas. Begitu pula halnya dengan penduduknya memiliki keanekaragaman dan perbedaan. Perbedaan merupakan keberagaman dan salah satu perbedaan tersebut adanya variasi pendidikan yang multicultural (Muhammad Anas Ma`arif, 2019). Keanekaragaman etnis dan budaya merpakan kebangaan Indonesia. Indonesia salah satu negara multikultur terbesar di dunia (Faridha \& Ali, 2015).

Hal ini dapat terlihat dari kondisi sosiokultural maupun geografis Indonesia yang begitu kompleks, beragam, dan luas. Indonesia terdiri atas sejumlah besar kelompok etnis, budaya, agama, dan lain-lain yang masing-masing plural (Lestari, 2016). Padangsidimpuan merupakan salah satu kota di Indonesia yang memiliki keanekaragaman agama yaitu agama Islam, Kristen Protestan, Katholik, Hindu dan Budha. Akan tetapi masyarakat pribumi Padangsidempuan lebih dikenal dengan istilah Tionghoa (Wekke, 2019b).

Tionghoa atau Tionghowa, adalah istilah yang dibuat sendiri oleh keturunan Cina di Indonesia. Asal katanya zhonghma dalam bahasa Mandarin. Zhonghua dalam dialek Hokkian dilafalkan sebagai Tionghoa. Keberagamaan dan perbedaan menunjukkan adanya identitas diri (Wekke, 2019a).

Identitas diri etnis Tionghoa muslim dilihat dari keterhubungannya dalam sosiologi pendiidkan. Gagasan di bidang pendidikan meliputi: lembaga pendidikan, format pengetahuan, pendidik profesional, (Zainiyati, 2016). Tingkat kemauan etnis Tionghoa muslim memperdalam ilmu agama sangatlah tinggi. Etnis Tionghoa muslim memperdalam ilmu agama di pusat-pusat kajian, seperti: masjid, perkumpulan keluarga mulim, majelis ilmu.

Disimpulkan bahwa etnis Tionghoa muslim yang beragam menjadi sebuah kekuatan dalam menyelenggarakan pendidikan keagamaan. Marga yang berbeda, identitas diri yang multikultural menjadi kekuatan dalam menciptakan persatuan dan kesatuan yang luhur (Christian, 2017).

\section{Penyelengaraan pendidikan keagamaan}

Kajian penyelenggaraan pendidikan keagamaan memuat kegiatan pendidikan, materi, metode, pendidik dan peserta didik. Penyelengaraan pendidikan keagamaan bergreat tujuan membentuk, mengembangkan dan memodifikasi ide dan perilaku seseorang atau kelompok. Education meaning are shaping, developing and behaviour of individual or groups (Suryadi et al., 2018).

Buku Dinamika Pendidikan Islam menyebutkan bahwa penyelengaraan pendidikan keagamaan merupakan uoya mengharmonikan identitas Isalam dana kebangsaan. Hal ini sesuai dengan hasil penelitian Marzuki bahwa Kewarganegaraan yang multikultural merupakan salah satu cara dalam membentuk karakter dengan menunjukkan integrasi nilai-nilai Islam dan kebangsaan (Samsuri \& Marzuki, 2016).

Sesuai juga dengan tujuan penyelenggaraan pendidikan keagamaan dalam QS. Adzariyah: 56 bahwa Allah tidak menciptakan jin dan manusia melainkan supaya mereka mengabdi kepadaKu.Tujuan 
penyelengaraan pendidikan keagmaan tercapai jika pendidikan itu sendiri dikelola dan diperhatikan sesuai dengan tujuan yang hendak dicapai dengan melibatkan keluarga dan masyarakat. Islam gives attention in education, such as formal education is madrasah, non formal education are: family and society (Supaat \& Fa'atin, 2019).

Dapat disimpulkan bahwa keluarga sangatlah berperan dalam menyelengarakan pendidikan keagamaan khususnya dalam lembaga pendidikan non formal (Aroma \& Suminar, 2012).

\section{Pendidikan keagamaan Islam di keluarga Etnis Tionghoa muslim.}

Pendidikan keagamaan diperoleh di lembaga pendidikan formal dan non formal. Penyelengaraan pendidikan keagmaan meliputi: pusat kajian pendidikan, materi, metode, pendidik dan peserta didik.(Asfiati, 2016). Pusat kajian pendidikan formal adalah sekolah. Pendidikan non formal berpusat di keluarga dan masyarakat. Center of education in the school and outside the school (Tjeppy, 2019).

Materi pelajaran memuat pengenalan sejarah Islamisasi etnis Tionghoa muslim. Islamisasi etnis Tionghoa muslim memuat kajian tentang hubungan siswa dengan kolega. Materials of education is relationships with student and colleagues (McIlveen et al., 2019). Metode pembelajaran mengkaji tentang kapasitas dan kualitas pembelaajran agar lebih unggul. Method of education have superior capacity and quality (Prasetyo, 2019).

Pendidik dan peserta didik memiliki konsep diri agar prestasi meningkat (Suryadi et al., 2018). Pendidik di lembaga pendidikan formal dan non formal mempunyai tugas yang sama. Dismpulkam pendidikan merupakan media yang strategis dalam menanamkan nilai-nilai kebaikan. Education is a strategis medium to instill the values of goodness (Rahmawati et al., 2018).

\section{Metode}

Metode penelitian ini adalah metode kualitatif memahami fenomena secara holistic dideskripsikan melalui redaksi bahasa yang mudah dipahami (Nasrudin, 2019). Proses penelitian melalui tahap orientasi, redaksi dan seleksi (Sugiarto, 2017). Pengembangan data lebih khusus terhadap ruang lingkup kajian (Luthfiyah, 2018). Instrumen pengumpulan data menggunakan observasi (Setiawan, 2018) dan wawancara (I Wayan Suwerndra, 2018). Teknik menjamin keabsahan data dengan triangulasi. (Sarmanu, 2017, p. Sar).

\section{Hasil dan Pembahasan}

\section{Kondisi Etnis Tionghoa muslim di Kota Padangidimpuan}

Berdasarkan data statistik kota Padangsidimpuan tahun 2016-2019 bahwa jumlah penduduk Tionghoa 2000 jiwa. Jumlah etnis Tionghoa muslim $10 \%$. Bintang, wawancara, 28 Juli 2017. Terdiri dari laki-laki 160 perempuan 40 (Muallim, wawancara, 28 Juli 2017). Etnis Tionghoa muslim menyebar di setiap kelurahan di kota Padangsidimpuan.

Tabel 1 Kondisi Etnis Tionghoa muslim Kota Padangsidimpuan

\begin{tabular}{|c|c|c|c|c|c|c|}
\hline \multirow[t]{2}{*}{ Domisili } & \multicolumn{2}{|c|}{ Jenis Kelamin } & \multicolumn{2}{|c|}{ Profesi } & \multicolumn{2}{|c|}{ Tingkat Pendidikan } \\
\hline & $\begin{array}{l}\text { Laki- } \\
\text { Laki }\end{array}$ & Pr & Pedagang & Pendidik & Sarjana & $\begin{array}{c}\text { Non } \\
\text { Sarjana }\end{array}$ \\
\hline $\begin{array}{l}\text { Kelurahan Sadabuan } \\
\text { (Wek I) }\end{array}$ & 60 & 40 & 80 & 20 & 65 & 35 \\
\hline $\begin{array}{l}\text { Kelurahan } \\
\text { Padangsidimpuan } \\
\text { Utara (Wek II) }\end{array}$ & 25 & 20 & 30 & 15 & 10 & 35 \\
\hline $\begin{array}{l}\text { Pusat kota } \\
\text { Padangsidimpuan } \\
\text { (Wek III) }\end{array}$ & 30 & 25 & 40 & 15 & 45 & 10 \\
\hline
\end{tabular}

Sumber: Dokumentasi Kelurahan Padangsidimpuan Utara Kota Padangsidimpuan 2016-2019.

Berdasarkan jenis kelamin, profesi dan tingkat pendidikan yang beragam menjadikan etnis Tionghoa muslim saling hidup rukun dan damai. Masing-masing saling hidup rukun dan saling membutuhkan baik yang muslim maupun non muslim (Rudi Hermanto, Pengawas Yayasan Vihara Budha Avalokitesvara, di 
Jalan Sudirman Kota Padangsidimpuan, Wawancara, 29 Juli 2017). Harmonisasi kerukunan cukup terjaga dengan saling punya rasa empati dan simpati.(Muhammad Asro'i Syahputra, Pengurus FKUB Kota Padangsidimpuan, Wawancara, 29 Juli 2017. Terjalinnya saling menghargai tidak lepas dari ikatan peradaban dan tatanan adat yang dikenal dengan Dalihan Natolu. Melalui Dalihan Natolu (Kahanggi, Mora dan Anakboru) menjadi satu kekuatan yang kompak dalam persatuan dan kesatuan (Observasi saat diadakannya acara pengajian di keluarga Tionghoa muslim 29 Juli 2017).

Keluarga etnis Tionghoa muslim sebagian besar berprofesi sebagai pedagang. (Data kelurahan menunjukkan mata pencaharian Tionghoa muslim 90\% adalah pedagang). Tingkat pendidikan $60 \%$ berpendidikan sarjana (Dokumentasi Kelurahan Padangsidimpuan Utara Kota Padangsidimpuan 20162019). Status dan latar belakang pendidikan menjadikan kepedulian dalam memajukan pendidikan. Pemerintah pun memberikan perhatian terhadap Tionghoa muslim dengan melibatkan mereka dalam kegiatan bakti sosial, anjang sana (Observasi kegiatan sosial ke panti asuhan di Ujung Gurap, 30 Juli 2017).

\section{Penyelenggaraan pendidikan keagamaan}

Program pendidikan keagamaan dijadwalkan sesuai dengan yang disepakati di berbagai majelis. Tenaga pengajar didatangkan dari berbagai disiplin ilmu. Peserta didiknya pun ada dari remaja putri, pemuda, ibuibu rumah tangga dan kaum bapak. Penyelenggaraan pendidikan keagamaan ada yang bersifat kelompok dan ada individu. Bersifat kelompok adalah melalui lembaga-lembaga kursus dan pelatihan, kelompok belajar, pusat kegiatan belajar, majelis taklim dan majelis ilmu (Melly Hidayah, Warga Etnis Tionghoa muslim di Padangsidimpuan, Wawancara, 29 Juli 2017).

Tabel 2. Kegiatan Pendidikan Keagamaan di Keluarga Tionghoa Muslim di kota Padangsidimpuan

\begin{tabular}{cccc}
\hline No & Jadwal & Kegiatan & Peserta \\
\hline $\mathbf{1}$ & Senin & Majelis Ta'lim kaum Ibu & Ibu-Ibu Tionghoa muslim \\
$\mathbf{2}$ & Selasa & Kajian Tajwid bagi Anak-Anak & Anak-anak usia SD 7-12 tahun \\
$\mathbf{3}$ & Rabu & Majelis Ilmu Kaum Bapak & Kaum Bapak Tionghoa muslim \\
$\mathbf{4}$ & Kamis & Siraman Rohani Remaja Putri & Remaja Putri Usia SMP-SMA \\
$\mathbf{5}$ & Jum'at & Pengajian Akbar & Keluarga Tionghoa muslim \\
$\mathbf{6}$ & Sabtu & Pelatihan Ibadah & Keluarga Tionghoa muslim \\
\hline
\end{tabular}

Sumber: Dokumentasi Pengurus Penyelengaraan Pendidikan Keagamaan Tionghoa Muslim kota Padangsidimpuan

Dari kalangan keluarga sendiri pun dibentuk pengajian-pengajian. Dapat melalui pendidikan agama di dalam keluarga yaitu dengan cara memanggil guru mengaji untuk mengajari ilmu-ilmu alquran dan tajwid, tentang tata cara melaksanakan ibadah (Zuhdi Salim, Warga Etnis Tionghoa muslim di Padangsidimpuan, Wawancara di perumahan warga, 15 Agustus 2017).

Disimpulkan materi ajar penyelenggaraan pendidikan adalah lebih dominan baca tulis alquran, tata cara salat, baik salat fardhu, jenazah dan salat-salat sunat lainnya (Yuyun Angraini, Warga Etnis Tionghoa muslim di Padangsidimpuan, Wawancara di perumahan warga, 15 Agustus 2017).

Anak-anak diberikan sekolah mengaji malam dan mencari sendiri di mana tempat pengajian yang layak mereka mendapatkan pendidikan keagamaan. Anak-anaklah sebagai peserta didik yang wajib mendapat pendidikan keagamaan (Evi Wijaya, Warga Etnis Tionghoa muslim di Padangsidimpuan, Wawancara di perumahan warga, 15 Agustus 2017). Pusat-pusat kajian pendidikan di rumah-rumah penduduk. Dari hasil pengamatan ada 15 keluarga yang menjadikan rumah mereka sebagai wadah membelajarkan ilmu agama Islam pada malam hari (Observasi ke pusat kajian pendidikan mengaji di rumah salah satu warga etnis Tionghoa muslim, 10 Agustus 2017).

Ulama pun ikut langsung mengajak anak-anak belajar Islam. (Melly Hidayah, Warga Etnis Tionghoa muslim di Padangsidimpuan, Wawancara di perumahan warga di Jalan. Sutan M.Arif Padangsidimpuan, 15 Agustus 2017). Tokoh-tokoh muslim Tionghoa tersebut langsung memperdalam ilmu agama dan berperan sebagai pendidik.(Observasi ke pusat kajian pendidikan mengaji di rumah salah satu warga etnis Tionghoa muslim, 10 Agustus 2017 Penyelenggaraannya pun kontiniu dan berkesinambungan, dan terorganisir (Observasi ke pusat kajian pendidikan mengaji di rumah salah satu warga etnis Tionghoa muslim, 10 Agustus 2017). 


\section{Pusat kegiatan pembelajaran agama (formal dan non formal)}

Rumah warga dijadikan wahana dalam mengajarkan Islam. Tempat-tempat ibadah serta madrasahmadarasah sebagai gedung bagi anak-anak mendapatkan ilmu agama. Madrasah Diniyah Awaliyah (MDA) juga merupakan pusat kegiatan mendapatkan ilmu agama. Bagi para remaja aula dari sekolah Sariputra dijadikan dalam melakukan perkumpulan-perkumpulan demi memperoleh pengetahuan agama Islam. Disimpulkan pusat kegiatan pembelajaran agama formal bagi anak-anak adalah di MDA, masjid dan di gedung-gedung madrasah ibtidaiyah. Bagi kaum muda berlokasi di aula-aula sekolah.

Pusat kegiatan di lembaga pendidikan non formal adalah di keluarga Tionghoa muslim itu sendiri. Di mana rumah dijadikan sebagai pusat kajiannya. Balai kantor camat serta aula di kantor kelurahan juga dijadikan tempat memperdalam ilmu agama. Pusat kegiatan pembelajaran agama non formal lainnya di lembaga kursus, lembaga pelatihan di antara sesama keluarga etnis Tionghoa muslim (Masrifah, Guru Pendidikan Agama Islam SMA Negeri 1 Padangsidimpuan, Wawancara, 20 Agustus 2017).

Pemanfaatan kantor Majelis Ulama Indonesia (MUI) juga dijadikan sebagai pusat menerima ilmu agama Islam. Kelompok-kelompok belajar serta majelis taklim dari berbagai kelurahan. (Adisareono, Tokoh muda perkumpulan remaja etnis Tionghoa muslim, Wawancara, 01 Agustus 2017). Etnis Tionghoa muslim di kota Padangsidimpuan senantiasa memiliki sikap dalam mengembangkan diri, mengembangkan profesi sebagai muslim yang kaffah (Evi Wijaya, Warga Etnis Tionghoa muslim di Padangsidimpuan, Wawancara di perumahan warga, 15 Agustus 2017). Melalui lembaga kursus etnis Tionghoa muslim di kota Padangsidimpuan mampu melaksanakan kegiatan ibadah dengan kekuatan iman.

\section{Kelompok belajar sebagai pusat kegiatan pendidikan non formal}

Kelompok belajar merupakan kumpulan dari pemuda muslim dan muslimah etnis Tionghoa muslim. Memanfaatkan balai desa sebagai tempat mengkaji agama Islam, dibuatlah kelompok belajar kajian Fikih. Dikembangkan dengan kelompok belajar Fikih Ibadah, Muamalah, Munakahat dan Warisan (Melly Hidayah, Warga Etnis Tionghoa muslim di Padangsidimpuan, Wawancara di perumahan warga, 19 Agustus 2017). Untuk kaum remaja muslimah memiliki kelompok belajar muslimah yang shalehah. Yaitu kelompok belajar yang membahas tentang kajian-kajian Fiqh Wanita (Yuyun Angrainy, Warga Etnis Tionghoa muslim di Padangsidimpuan, Wawancara di perumahan warga, 20 Agustus 2017).

Kajian tentang Thaharoh, Cara Berpakaian muslimah dan juga akhlak bergaul sesama muslim (Meriati Yuni, Tokoh muda perkumpulan remaja-remaja Tionghoa muslim, Wawancara, 01 Agustus 2017). Kelompok-kelompok belajar ini terjadwal sesuai dengan kesepakatan. Metode yang dilakukan ceramah dan diskusi serta tanya jawab tentang kajian-kajian keislaman khususnya tentang kewanitaan. Kelompok belajar lainnya adalah kelompok belajar keluarga yaitu melibatkan orang tua dan anak. Kelompok belajar keluarga ini diprakarsai dan didanai satu orang keluarga besar etnis Tionghoa muslim dan dilaksanakan di rumahnya saja sebagai donator tunggal (Nurhayati Tan, wakil Ketua Majelis Taklim Etnis Tionghoa muslim Kota Padangsidimpuan di Padangsidimpuan, Wawancara 21 Agustus 2017).

Tujuan pokok pembentukan kelompok belajar pendidikan keagamaan adalah :1) Untuk memberikan kesempatan bagi setiap warga untuk maju sesuai dengan kemampuannya masing-masing dan cara memperdalam ilmu agama, mengkaji dan mengamalkannya; 2) Sebagai wadah belajar bersama, mengkaji ilmu agama secara bersama dan mempunyai kemauan yang sama serta motivasi untuk memperoleh ilmu sebagai bekal di dunia dan akhirat.

Melalui kelompok belajar diharapkan mempunyai kesempatan untuk maju sesuai dengan kemampuan yang dimiliki. Adapun prosedur kelompok belajar dikelompokkan jangan terlalu banyak dan terlalu sedikit. Untuk itu dapat digunakan rentangan 3 sampai 5 kelompok. (Masrifah, Guru Pendidikan Agama Islam SMA Negeri 1 Padangsidimpuan, Wawancara, 20 Agustus 2017). Dengan 4 kelompok: masingmasing dibuat nama kelompoknya sesuai dengan materi yang dibahas. Misalnya kelompok Umaar bin Khattab, Ali bin Abi Thalib, Abu Bakar Siddik, dan Usman bin Affan.

\section{Majelis taklim sebagai lembaga kegiatan pendidikan non formal}

Pusat kegiatan pendidikan non formal lainnya berpusat di majelis-majelis taklim. Majelis taklim merupakan wadah organisasi sebagai tempat perkumpulan orang banyak dalam rangka mengikuti pengajaran agama Islam. Etnis Tionghoa muslim menjadikan majelis taklim sebagai wahana untuk medapatkan berbagai pengajaran agama Islam sesuai dengan kebutuhan para jama'ahnya (Sulistiwowati, Ketua Majelis Taklim Etnis Tionghoa Muslim Kota Padangsidimpuan, Wawancara, 11 Agustus 2017). 
Majelis taklim sebagai lembaga pendidikan non formal Islam memiliki kurikulum tersendiri, diselenggarakan secara berkala dan teratur, dan diikuti oleh jama'ah yang relatif banyak. Majelis taklim bertujuan untuk membina dan membangun hubugan yang santun dan serasi antara masyarakat muslim Tionghoa di Padangsidimpuan dalam rangka membina masyarakat yang bertakwa kepada Allah SWT (Nurhayati Tan, wakil Ketua Majelis Taklim Etnis Tionghoa muslim Kota Padangsidimpuan di Padangsidimpuan, Wawancara 21 Agustus 2017).

Keberadaan majelis taklim memiliki peran yang sangat penting dalam laju perkembangan masyarakat. Majelis taklim di pengajian etnis Tionghoa muslim berfungsi sebagai berikut: 1) Lembaga yang membina dan mengembangkan ajaran Islam dalam rangka membentuk masyarakat yang bertakwa kepada Allah SWT; 2) Taman rekreasi rohaniah, karena penyelenggaraannya bersifat santai. Penyelenggaraan dilakukan dari rumah ke rumah anggota. Rasa persaudaraan dan kekeluargaan semakin kuat meskipun jumlah etnis Tionghoa muslim di Padangsidimpuan relatif sedikit; 3) Wadah perkumpulan silaturrahmi masal yang dapat menghidup suburkan dakwah dan ukhuwah Islamiah; 4) Tukar pikiran antara ilmuwan, agamawan dan umara; 5) Media penyampaian gagasan yang bermanfaat bagi pembangunan umat bangsa pada umumnya (Sukaesih, Sekretaris Majelis Taklim Etnis Tionghoa muslim Kota Padangsidimpuan di Padangsidimpuan, Wawancara 12 Agustus 2017).

Helmawati menuturkan bahwa majelis taklim sebagai lembaga pendidikan nonformal memiliki beberapa fungsi, diantaranya: 1) Fungsi keagamaan, yakni membina dan mengembangkan ajaran Islam dalam rangka membentuk masyarakat yang beriman dan bertakwa kepada Allah SWT; di mana etnis Tionghoa muslim selalu rajin dalam memperdalam ilmu-ilmu agama; 2) Fungsi pendidikan, yakni menjadi pusat kegiatan belajar masyarakat (learning society), keterampilan hidup, dan kewirausahaan; Memperoleh banyak keahlian, tentang salat berjamaah, salat jenazah, memandikan dan mensalatkan jenazah; 3) Fungsi sosial, yakni menjadi wahana silaturrahim, menyampaikan gagasan, dan sekaligus sarana dialog antara ulama, umara, dan umat; 4) Fungsi ekonomi, yakni sebagai sarana tempat pembinaan dan pemberdayaan ekonomi jama'ahnya; 5) Fungsi ketahanan bangsa, yakni menjadi wahana pencerahan umat dalam kehidupan beragama, bermasyarakat, dan berbangsa

\section{Materi pembelajaran}

Materi pembelajaran berisi ajaran Islam dengan segala aspeknya. Bahan atau materi pengajarannya berupa: Tafsir, Hadis, Fiqh, Tasawuf, Tarikh Islam, Bahasa Arab, ataupun masalah-masalah kehidupan yang ditinjau dari aspek ajaran Islam (Helmawati, Wakil Sekretaris Majelis Taklim Etnis Tionghoa muslim Kota Padangsidimpuan di Padangsidimpuan, Wawancara 12 Agustus 2017).

Materi-materi pembelajaran dituangkan dalam buku atau kitab sesuai dengan perkembangan pemahaman keagamaan para jama'ah. Buku dan kitab yang digunakan berupa buku berbahasa Indonesia ataupun kitab yang berbahasa Arab. Bahkan tidak menutup kemungkinan, para Ustadz membuat semacam diktat atau buku pedoman (modul) sebagai materi ajar bagi para jama'ah (Masrifah, Guru Pendidikan Agama Islam SMA Negeri 1 Padangsidimpuan, Wawancara, 20 Agustus 2017).

Memudahkan memahami materi pembelajraan, disusun materi secara terstruktur dan tidak terstruktur. Materi yang terstruktur adalah program kurikulum yang mengikuti program yang telah ditetapkan. Materi pembelajran yang tidak terstruktur adalah program kajian yang tidak ditetapkan atau disusun dahulu. Materi yang akan diberikan pada jama'ah tergantung pemateri atau ustadz yang ditunjuk pengelola (Nurhayati Tan, wakil Ketua Majelis Taklim Etnis Tionghoa muslim Kota Padangsidimpuan di Padangsidimpuan, Wawancara 21 Agustus 2017).

Materi yang dipelajari mencakup akidah, ibadah, dan akhlak. Kegiatan pendidikan keagamaan Islam etnis Tionghoa muslim di Kota Padangsidimpuan dilaksanakan 1 x dalam 1 bulan yaitu minggu kedua setiap hari Jum'at pukul 16.00 Wib (Nurhayati Tan, wakil Ketua Majelis Taklim Etnis Tionghoa muslim Kota Padangsidimpuan di Padangsidimpuan, Wawancara 21 Agustus 2017). Adapun kegiatan-kegiatan yang diselenggarakan etnis Tionghoa muslim kota Padangsidimpuan adalah: 1) Pengajian rutin, pengajian tersebut dilakukan secara terus menerus sesuai dengan waktu yang disepakati bersama, 2) Melakukan kegiatan peringatan hari-hari besar Islam, seperti peringatan maulid Nabi Muhammad SAW, peringatan Isra' Mi'raj Nabi Muhammad SAW, penyambutan bulan suci Ramadhan, dan lain-lain, dan 3) Kegiatan sosial lainnya. Dalam bidang sosial dapat dilakukan berupa kebersihan lingkungan, rumah ibadah, memberikan bantuan baik berupa materi maupun moril kepada anggota majelis yang ditimpa musibah, 
tepung tawar jamaah haji dan lain sebaginya (Ayen, Bendahara, Majelis Taklim Etnis Tionghoa muslim Kota Padangsidimpuan di Padangsidimpuan, Wawancara 21 Agustus 2017).

\section{Metode pembelajaran}

Metode yang digunakan dalam pendidikan keagamaan Islam etnis Tionghoa muslim kota Padangsidimpuan adalah sebagai berikut: 1) Metode ceramah, terdiri dari ceramah umum yaitu ustadz yang bertindak aktif memberikan pengajaran sementara jama'ah pasif, dan ceramah khusus yaitu pengajaran dan jama'ahnya sama-sama aktif dalam berdiskusi; 2) Metode halaqoh, yaitu pengajaran membaca kitab tertentu sementara jama'ah mendengarkan; 3) Metode campuran, yaitu melaksanakan berbagai metode sesuai dengan kebutuhan (Evi Wijaya, Warga dan sebagai jamaah Majelis Taklim Etnis Tionghoa muslim di Padangsidimpuan, Wawancara di perumahan warga, 15 Agustus 2017).

Metode pendidikan yang dilakukan diharapkan dapat membangun pembelajaran. Pembelajaran yang menciptakan interaksi antara pendidik dan peserta didik. Temuan ini mendukung teori dari Suhendra dan kakawan-kawan bahwa: education process that put emphasis of meaningfull interaction between teacher and student (Sukendar et al., 2019). Kebermaknaan pembelajaran melalui metode yang sesuai dengan kemampuan berfikir dan kreatif pendidik dan peserta didik.

\section{Pendidik dan peserta didik}

Keberhasilan pendidikan keagamaan Islam etnis Tionghoa muslim di kota Padangsidimpuan didukung oleh peserta didik yang aktif dan pendidik yang kreatif. Di pendidikan formal, pendidik ditanggungjawabi oleh guru. Pendidik di etnis muslim Tionghoa di Sekolah Dasar Sariputra berasal dari berbagai latar belakang. Guru pendidikan agama Islam adalah ibu Mustika Wardah latar belakang pendidikannya dari Institut Agama Islam Negeri (IAIN) Padangsidimpuan.

Berdasarkan sejarah Tionghoa muslim di kota Padangsidimpuan bukan dari penyebar agama Islam. Dengan demikian pendidik di sekolah non formal tidaklah semuanya paham betul dengan Islam. Akan tetapi Islam dipahami dan dikenal setelah berbaur dengan masyarakat Islam pribumi kota Padangsidimpuan. Temuan ini sesuai dengan teori Kurniawan bahwa Tionghoa muslim Indonesia also gives explanation that generation Chinese immigrant (Kurniawan, 2017). Adanya banyak intrepretasi Tionghoa muslim di kota Padanagsidimpuan dari berbagai generasi yang immigrant dengan demikian pendidik non formal baik di keluarga dan masyarakat memiliki multikultural yang beragam.Pendidik yang beragam berarti beragam tingkat kemampuan keagamaannya dan menjadikan semangat belajar bersama di antara sesame peserta didik. Di mana peserta didik di pendidikan formal juga sesuai dengan asal-usul keluarga Tionghoa muslim di kota Padangsidimpuan.

\section{Pembahasan}

Pendidikan keagamaan Islam diselenggarakan oleh setiap umat Islam. Setiap muslim wajib mempelajari, mempedomani dan mengamalkan ajaran agama Islam. Islam sebagai agama universal, sebagai agama bagi manusia (umat manusia). Islam sebagai agama untuk seluruh dunia. Misi Islam sebagai rahmat untuk semua makhluk (Hunaida, 2016).

Masyarakat etnis Tionghoa muslim menjadikan Islam sebagai rahmatan lil alamin. Di mana berupaya mensinergikan dan mendinamisasikan melalui penyelengaraan keagamaan secara dinamik. Kegiatan penyelenggaraan keagamaan terfokus kepada kegiatan ibadah. Kegiatan ibadah mampu meningkatkan kegiatan akhlakul karimah. Ibadah berlandaskan syariah menghasilkan akhlak yang mencerminkan nilainilai ajaran Islam.

Penyelenggaraan pendidikan keagamaan Islam pada etnis Tionghoa muslim merupakan hal yang harus tetap digali mulai dari pengkajian ilmu hingga pendalaman dan pengamalannya. Terselenggaranya pendidikan keagamaan Islam berawal dari pokok dasar ajaran agama Islam yaitu aqidah, syariah dan akhlak. Pokok dasar agama Islam tersebut diajarkan di lembaga pendidikan formal dan non formal. Lembaga pendidikan sebagai pusat kegiatan keagamaan (Jahroni, 2016).

Penelitian ini memberikan perhatian penuh bahwa etnis Tionghoa muslim mau berbuat dan belajar. Belajar tentang Islam, persaudaraan, silaturrahim dan juga kajian-kajian ibadah lainnya. Etnis Tionghoa muslim membuktikan keberadaannya di kota Padangsidimpuan sebagai bagian dari warga muslim dan warga masyarakat Islam di Indonesia menjunjung tinggi nilai-nilai ajaran Islam. Penelitian ini merekomendasikan menggali sarana-sara pendidikan Islam baik yang terorganisir ataupun lembaga sesuai 
dengan perkembangan masyarakat muslim Padangsidimpuan. Penelitian ini sebaiknya membahas bahwa penyelenggaraan keagamaan yang dilakukan etnis Tionghoa muslim di kota Padangsidimpuan membuktikan bahwa Islam bertahan di mana dan di kelompok apa saja. Islam adalah rahmatan lilalamin. Islam adalah uswatun dan selalu membawa pengabdian untuk sang pencipta. Etnis Tionghoa muslim menjadi pelopor tegaknya memperjuangkan nilai-nilai ajaran Islam. Penyelenggaraan keagamaan berjalan dinamis sesuai dengan banyaknya kegiatan yang dilaksanakan. Dinamika penyelenggaraan keagamaan berlangsung penuh dengan saling memberikan masukan demi untuk memperbaiki keutuhan dan kemampuan dalam berbuat dan mengamalkan ajaran Islam.

\section{Kesimpulan}

Kondisi etnis Tionghoa muslim di kota Padangsidimpuan adalah minoritas. Jumlah totalnya hanya $10 \%$ dari 2000 warga Tionghoa. Etnis Tionghoa muslim di kota Padangsidimpuan menyebar di setiap kelurahan. Etnis Tionghoa muslim mengkaji ilmu-ilmu aqidah, syariah dan akhlak. Dinamika penyelengaaraan pendidikan keagamaan Islam etnis Tionghoa muslim di kota Padangsidimpuan berbaur dengan masyarakat muslim pribumi lainnya yang berada di Padangsidimpuan secara natural dan agamis. Penyelenggaraan pendidikan keagamaan Islam etnis Tionghoa muslim berkembang sesuai dengan bertambah banyaknya etnis Tionghoa muslim di kota Padangsidimpuan. Dinamika penyelenggaraan pendidikan keagamaaan Islam etnis muslim di kota Padangsidimpuan terlaksana dalam berbagai wadah dan sarana. Penyelenggaraan pendidikan keagamaan ada berdasarkan kelompok dan individu.

\section{Referensi}

A`la, A., Mukarrom, A., \& Zamzami, M. (2019). Islam Dan Agamaisasi Politik: Studi Analisis Terhadap Peran Dan Pergerakan Forum Kiai Muda (FKM) Pamekasan Madura. Jurnal Review Politik, 8(1), hal. i.

Aroma, I. S., \& Suminar, D. R. (2012). Hubungan antara Tingkat Kontrol Diri dengan Kecenderungan Perilaku Kenakalan Remaja. Jurnal Psikologi Pendidikan Dan Perkembangan, 1(2), hal. 4.

Asfiati. (2016). Pendekatan humanis dalam pengembangan kurikulum. Perdana Publishing.

Asfiati, A. (2014). Sekuralitas Dan Spiritualitas:(Mencari Format dan Integrasi Ilmu untuk Konstruksi Kurikulum Pendidikan Islam). Darul Ilmi, 2(2).

Christian, S. A. (2017). Identitas Budaya Orang Tionghoa Indonesia. Jurnal Cakrawala Mandarin, $1(1), 11$. https://doi.org/10.36279/apsmi.v1i1.11

Damayanti, N. P., Thayibi, I., Gardhiani, L. A., \& Limy, I. (2003). Radikalisme Agama Sebagai Salah Satu Bentuk Perilaku Menyimpang: Studi Kasus Front Pembela Islam. Indonesian Journal of Criminology, $3(1)$.

Faridha, R., \& Ali, N. H. (2015). Islam Di Cina Pada Masa Pemerintahan Republik Nasionalis, 1911-1949. TAMADDUN: Jurnal Kebudayaan Dan Sastra Islam, 15(2), 1-38.

Fauzi, A., \& Nikmatullah, C. (2016). Pelaksanaan Pendidikan Madrasah Diniyah di Kota Serang( Implementation of Islamic Education in Serang City). Jurnal Pendidikan dan Kebudayaan, 1(2), hal. 159.

I Wayan Suwerndra, I. W. S., S. Pd. (2018). Metodologi Penelitian Kualitatif dalam Ilmu Sosial, Pendidikan, Kebudayaan dan Keagamaan. Nilacakra.

Ibrahim, N. (2016). Islam di China (Masa Dinasti Ming 1368-1644 M). Rihlah: Jurnal Sejarah dan Kebudayaan, 4(1). https://doi.org/10.24252/rihlah.v4i1.2574

Jahroni. (2016). Islamisasi Pantai Utara Jawa: Menelusuri Penyiaran Islam di Tanah Betawi I. Jurnal Lektur Keagamaan,

14(2). https://jurnallekturkeagamaan.kemenag.go.id/index.php/lektur/article/view/506/334

Kurniawan, H. (2017). The Role of Chinese in Coming of Islam To Indonesia:Teaching Materials Developmnet Based on Muliticulturalism. Paramita: Historical Studies Journal, 27(2), 238-248.

Lestari, G. (2016). Bhinnekha Tunggal Ika: Khasanah Multikultural Indonesia Di Tengah Kehidupan SARA. Jurnal Pendidikan Pancasila Dan Kewarganegaraan, 28(1).

Luthfiyah, M. F. \&. (2018). Metodologi penelitian: Penelitian kualitatif, tindakan kelas \& studi kasus. CV Jejak (Jejak Publisher). 
Mahfud, C. (2018). Chinese Muslim Community Development in Contemporary Indonesia: Experiences of PITI in East Java. Studia Islamika, 25(3), hal.476. https://doi.org/10.15408/sdi.v25i3.6755

McIlveen, P., Perera, H. N., Baguley, M., Van Rensburg, H., Ganguly, R., Jasman, A., \& Veskova, J. (2019). Impact of teachers' career adaptability and family on professional learning. Asia-Pacific Journal of Teacher Education, 47(2), 5.

Muhammad Anas Ma`arif. (2019). Internalisasi Nilai Multikulutural Dalam Mengembangkan Sikap Toleransi ( Studi Di Di Pesantren Mahasiswa Universitas Islam Malang) | Nazhruna: Jurnal Pendidikan Islam. Nazhruna: Jurnal Pendidikan Islam, 2(1), hal. https://doi.org/10.31538/nzh.v2i1.179

Nasrudin, J. (2019). Metodologi Penelitian Pendidikan: Buku ajar praktis cara membuat penelitian. Pantera Publishing.

Oktafia, R., \& Mawardi, I. (2017). Islamic Values in The Tradition of Samin Community at East Java. QIJIS (Qudus International Journal of Islamic Studies), 5(1), hal. 105. https://doi.org/10.21043/qijis.v5i1.2027

Prasetyo, K. B. (2019). Structural and Cultural Aspects as the Potentials in the Development of Alternative Education for Fishermen Community. Komunitas, 11(1), hal. 3.

Pratiwi, F. I., Saraswati, D. P., \& Muttaqien, M. (2018). Does the rise of China present a threat to the interests of the United States? Masyarakat, Kebudayaan Dan Politik, 31(4), 350-357. https://doi.org/10.20473/mkp.V31I42018.350-357

Samsuri, S., \& Marzuki, M. (2016). Pembenatukan Karakter Kewarganegaraan Multikultural Dalam Program Kurikuler di Madrasah Aliyah Se Daerah istimewa Yogyakarta. Jurnal Cakrawala Pendidikan, 35(1), 1. https://doi.org/10.21831/cp.v1i1.8362

Sarmanu. (2017). Dasar Metodologi Penelitian Kuantitatif Kualitatif dan Statistika. Airlangga University Press.

Setiawan, A. A., Johan. (2018). Metodologi penelitian kualitatif. CV Jejak (Jejak Publisher).

Sugiarto, E. (2017). Menyusun Proposal Penelitian Kualitatif: Skripsi dan Tesis: Suaka Media. Diandra Kreatif.

Sukendar, A., Usman, H., \& Jabar, C. S. A. (2019). Teaching, Loving, Caring Asah-Asih-Asuh) and Semi Military Education Character Education Management. Jurnal Cakrawala Pendidikan, 38(2), $292-304$. https://doi.org/10.21831/cp.v38i2.24452

Supaat, S., \& Fa'atin, S. (2019). The Muslim Millennial family typology: The role of Muslim family circumflex model to avoid parents' violent behavior against children in Indonesia. Indonesian Journal of Islam and Muslim Societies, 9(1), hal. 61. https://doi.org/10.18326/ijims.v9i1.57-81

Suryadi, B., Soriha, E., \& Rahmawati, Y. (2018). Pengaruh Gaya Pengasuhan Orang Tua, Konsep Diri, Dan Regulasi Diri Terhadap Motivasi Berprestasi Siswa. Jurnal Ilmu Pendidikan, 23(2), hal. 95. https://doi.org/10.17977/jip.v23i2.10969

Tjeppy, T. (2019). Understanding Of Religious Values As A Means To Prevent Violence In Educational Institutions In Indonesia. MIMBAR: Jurnal Sosial Dan Pembangunan, 35(1), hal. 194. https://doi.org/10.29313/mimbar.v35i1.4398

Wekke, I. S. (2019a). Bugis and Madura Migration in Nusantara: Religiosity, Harmony, and Identity from Eastern Indonesia - ProQuest. Ulul Al Bab Malang, 20(1), h.18. https://doi.org/10.18860/ua.v20i1.4902

Wekke, I. S. (2019b). Perjumpaan Agama dan Tradisi Masyarakat Sulawesi Selatan: Bacaan Terhadap Buku Islamisasi Bugis [Preprint]. INA-Rxiv. https://doi.org/10.31227/osf.io/8qjhg

Wekke, I. S., \& Rusdan, R. (2017). Minoritas Muslim di China: Perkembangan, Sejarah Dan Pendidikan. Ijtimaiyya: Jurnal Pengembangan Masyarakat Islam, 10(1), $143-174$. https://doi.org/10.24042/ijpmi.v10i1.2359

Zainiyati, H. S. (2016). Curriculum, Islamic Understanding And Radical Islamic Movements In Indonesia. Journal Of Indonesian Islam, 10(2), h.305. https://doi.org/10.15642/JIIS.2016.10.2.285-308 